\title{
KONSEP BIMBINGAN DAN KONSELING DI SEKOLAH
}

\author{
Beta Kurnia Illahi \\ Universitas Negeri Padang \\ E-mail : betakurnia0206@gmail.com
}

\begin{abstract}
Abstrak: Bimbingan dan konseling merupakan suatu proses pemberian bantuan secara sistematis dan berkelanjutan kepada peserta didik untuk membantu menyelesaikan masalah yang dihadapinya dan agar peserta didik tersebut dapat memahami dirinya dan menyesuaikan diri dengan lingkungannya. Layanan bimbingan dan konseling bertujuan untuk membantu peserta didik agar mampu mengembangkan dirinya secara optimal dan dapat menyesuaikan diri dengan lingkungannya. Layanan Bimbingan dan konseling sangat dipenting di lingkungan sekolah agar peserta didik dapat berkembang secara optimal.
\end{abstract}

\section{Kata kunci : Bimbingan dan Konseling, Tujuan, Fungsi dan Sekolah}

Abstract: Guidance and counseling is a process of providing assistance systematically and continuously to students to help solve the problems they face and so that these students can understand themselves and adapt to their environment. Guidance and counseling services aim to help students to be able to develop themselves optimally and be able to adapt to their environment. Guidance and counseling services are very important in the school environment so that students can develop optimally.

Keywords: Guidance and Counseling, Purpose, Function and School

\section{PENDAHULUAN}

Sekolah merupakan salah satu lembaga pendidikan, sebegai salah satu lembaga pendidikan, sekolah membutuhkan pelayanan BK dalam penyelenggaraan dan peningkatan kehidupan sekolah dan tercainyan visi misi profesi konseling. Layanan bimbingan dan konseling di sekolah merupakan suatu usaha membantu peserta didik dalam pengembangan kehidupan, baik kehidupan pribadi, kehidupan sosial, kegiatan belajar, maupun perencanaan dan pengembangan karir. memberi pelayanan bimbingan dan konseling berarti memfasilitasi pengembangan peserta didik secara individual, kelompok, dan atau klasikal, sesuai dengan kebutuhan, potensi, bakat, minat, perkembangan, kondisi, serta peluang-peluang yang dimiliki. Layanan 
bimbingan dan konseling juga membantu mengatasi kelemahan dan hambatan serta masalah yang dihadapi peserta didik.

Bimbingan dan konseling sangat penting di lingkungan sekolah, kareana masingmasing peserta didik di lingkungan sekolah memiliki latar belakang sosial yang berbeda antara individu yang satu dengan individu yang lain ketika menghadapi lingkungan sekolah. Karena terdapat perbedaan tentu aja ada peserta didik yang kurang bisa menyesuaikan diri dengan lingkungan barunya. Baik karena lingkungan, sesehatan mental, maupun alasan-alasan lainnya. Oleh karena itulah bimbingan konseling sangat penting bagi lingkungan sekolah.

\section{PEMBAHASAN}

\section{Pengertian Bimbingan dan Konseling}

Bimbingan merupakan suatu kegiatan atau proses yang diberika kepada peserta didik secara berkelanjutan agar dapat memahami dirinya sendiri dan menyesuaikan diri dengan lingkungannya. Sedangkan konselor sebagai hubungan timbal balik antara guru bk dan peserta didik. Pelayanan Bimbingan dan konseling didefinisikan sebagai pelayanan bantuan untuk peserta didik, secara perorangan maupun kelompok agar mandiri dan bisa berkembang secara optimal, dalam bimbingan pribadi, sosial, belajar maupun karier melalui berbagai bentuk layanan serta kegiatan pendukung berdasarkan norma-norma yang berlaku.

Rochman Natawidjaja menjelaskan bimbingan sebagai suatu proses berkesinambungan supaya individu tersebut dapat memahami dirinya sehingga dia sanggup mengarahkan dirinya dan dapat berperilaku secara wajar, sesuai dengan tuntutan dan keadaan lingkungan sekolah, keluarga, masyarakat, dan kehidupan pada umumnya. Sehingga siswa akan dapat menikmati kebahagiaan hidupnya, dan dapat memberi sumbangan yang berarti kepada kehidupan masyarakat pada umumnya. Bimbingan membantu individu mencapai perkembangan diri secara optimal sebagai makhluk sosial.

Dari pengertian-pengertian di atas, dapat disimpulkan bahwa bimbingan adalah suatu proses pemberian bantuan yang terus menerus dan sistematis kepada individu dalam memecahkan masalah yang dihadapinya, agar tercapai kemampuan untuk dapat memahami dirinya sendiri , menerima dirinya dengan apa adanya , mengarahkan dirinya dan merealisasikan dirinya sesuai dengan potensi atau kemampuannya dalam mencapai penyesuaian diri dengan lingkungannya, baik keluarga, sekolah maupun masyarakat. 


\section{Tujuan Bimbingan dan Konseling}

Layanan bimbingan konseling bertujuan untuk membantu siswa agar siswa dapat mencapai tujuan perkembangan disegala aspek, baik aspek pribadi, aspek sosial, aspek belajar dan aspek karir.tujuan dari Bimbingan pribadi-sosial merupakan untuk mencapai tujuan dan tugas perkembangan pribadi-sosial dalam mewujudkan pribadi yang taqwa, mandiri dan bertanggung jawab. Adapun tujuan dari BK secara umum yaitu: 1) Mampu menyesuaikan diri; 2) Mampu menyelesaikan masalah; 3) Mengembangkan life skills 4) mengembangkn sikap positif: 5) Memiliki rasa tanggung jawab; 6) Mampu Merencanakan masa depan; 7) Dapat mencapai tugas perkembangan; dan 8) Mampu meraih life welfare

Tujuan pemberian layanan bimbingan menurut Achmad Juntika Nurihsan (2006:8) adalah sebagai berikut: a) Agar individu dapat merencanakan kegiatan penyelesaian studi, perkembangan karir, dan kehidupannya pada masayang akan dating; b) Mengembangkan seluruh potensi dan kekuatan yang dimilikinya seoptimal mungkin: c) Menyesuaikan diri dengan lingkungan pendidikan, lingkungan masyarakat dan lingkungan kerjanya; d) Mampu mengatasi apapun masalah berupa hambatan dan kesulitan yang dihadapi dalam melaksanakan pendidikan, penyesuaian dengan lingkungan pendidikan, masyarakat ataupun lingkungan kerja.

\section{Fungsi Pelayanan BK}

Fungsi bimbingan dan konseling berdasarkan sifatnya, yaitu: 1) Fungsi preventif; dilakukan dengan membantu individu atau peserta didik dalam menjaga atau mencegah timbulnya masalah bagi dirinya; 2)Fungsi kuratif atau korektif; dilakukan dengan membantu individu memecahkan masalah yang terjadi padanya; 3) Fungsi preservatif; merupakan membantu individu menjaga agar situasi dan kondisi yang semula tidak baik (mengandung masalah) menjadi baik (terpecahkan) dan kebaikan itu bertahan lama; 4) Fungsi terapi; yaitu membantu individu membebaskan dan melepaskan dirinya dari segala kekhawatiran dan kegelisahannya dalam menghadapi masalah yang dihadapinya; 5) Fungsi developmental atau pengembangan; yaitu membantuindividu memelihara dan mengembangkan situasi dan kondisi yang telah baik agar tetap baik atau menjadi lebih baik, sehingga tidak memungkinkannya menjadi sebab munculnya masalah bagi diri klien; 6) Fungsi penyaluran; yaitu fungsi bimbingan dalam membantu individu memilih dan memantapkan penguasaan karir atau jabatan yang sesuai dengan minat, bakat, keahlian dan ciri- ciri kepribadian lainnya; 7) Fungsi penyesuaian; yaitu fungsi bimbingan dalam membantu individu menemukan penyesuaian diri dan perkembangannya secara optimal. 


\section{KESIMPULAN}

Bantuan yang diberikan kepada siswa dalam rangka upaya menemukan pribadi, mengenalkan lingkungan serta merencanakan masa depan merupakan bentuk dari bimbingan. Bimbingan dan konseling merupakan salah satu komponen dalam keseluruhan sistem pendidikan khususnya di sekolah, guru sebagai salah satu pendukung unsur pelaksanaan pendidikan yang mempunyai tanggung jawab sebagai pendukung pelaksana pelayanan bimbingan pendidikan di sekolah, di tuntut dan diharapkan memiliki wawasan yang memadai terhadap konsep-konsep dasar bimbingan dan konseling di sekolah. Tujuan khusus dari layanan bimbingan konseling merupakan untuk membantu siswa agar mencapai tujuan-tujuan perkembangan meliputi aspek-aspek antara lain: pribadi, sosial, belajar, dan karir. Adapun fungsi pelaksanaan bimbingan dan konseling adalah fungsi prevetif, fungsi kuratif dan korektif, fungsi presevatif, fungsi terapi, fungsi developmental, fungsi penyaluran dan fungsi pelaksanaan.

\section{DAFTAR PUSTAKA}

Abin Syamsuddin Makmun. 2003. Psikologi Pendidikan. Bandung : PT Rosda Karya Remaja.

Dewa Ketut Sukardi. 1988. Bimbingan dan Konseling. Jakarta : Bina Aksara

Kamaluddin. 2011. Bimbingan dan Konseling Sekolah. Jurnal Pendidikan dan Kebudayaan. Vol. 17 No 4.

Nurihsan, Achmad Juntika. 2011. Bimbingan dan Konseling dalam Berbagai Latar Kehidupan. Bandung: PT Refika Aditam

Masdudi. 2015. Bimbingan dan Konseling Persfektif Sekolah. Cirebon: Nurjati Press

Mugiarso, Heru. et al. 2011. Bimbingan dan Konseling. Semarang: Unnes Press

Prayitno. 2004. Dasar-dasar Bimbingan dan Konseling. Jakarta: Rineka Cipta

Prayitno. 2004b. Pedoman Khusus Bimbingan dan Konseling. Jakarta: Direktorat Jenderal Pendidikan Dasar dan Menengah, departemen Pendidikan Nasional. 